\title{
Wavelet Transform Based Fault Identification and Reconfiguration for a Reduced Switch Multilevel Inverter Fed Induction Motor Drive
}

\author{
Arigela Satya Veerendra ${ }^{1,2} \mathbb{D}$, Akeel A. Shah ${ }^{1, *}$, Mohd Rusllim Mohamed ${ }^{2, *}$, Chavali Punya Sekhar ${ }^{3}$ \\ and Puiki Leung 1 \\ 1 Key Laboratory of Low-grade Energy Utilization Technologies and Systems, MOE, Chongqing University, \\ Chongqing 400030, China; veerendraump@gmail.com (A.S.V.); leungpuiki@hotmail.com (P.L.) \\ 2 College of Engineering, Universiti Malaysia Pahang, Gambang, Kuantan 26300, Pahang, Malaysia \\ 3 Department of Electrical \& Electronics Engineering, Acharya Nagarjuna University, NH16, Nagarjuna Nagar, \\ Guntur, Andhra Pradesh 522510, India; punya286@gmail.com \\ * Correspondence: akeel.shah@cqu.edu.cn (A.A.S.); rusllim@ump.edu.my (M.R.M.)
}

check for updates

Citation: Veerendra, A.S.; Shah, A.A.; Mohamed, M.R.; Sekhar, C.P.; Leung, P. Wavelet Transform Based Fault Identification and Reconfiguration for a Reduced Switch Multilevel Inverter Fed Induction Motor Drive. Electronics 2021, 10, 1023. https:// 10.3390/electronics10091023

Academic Editor: Antonio J. Marques Cardoso

Received: 4 March 2021

Accepted: 13 April 2021

Published: 25 April 2021

Publisher's Note: MDPI stays neutral with regard to jurisdictional claims in published maps and institutional affiliations.

Copyright: (c) 2021 by the authors. Licensee MDPI, Basel, Switzerland. This article is an open access article distributed under the terms and conditions of the Creative Commons Attribution (CC BY) license (https:/ / creativecommons.org/licenses/by/ $4.0 /)$.

\begin{abstract}
The multilevel inverter-based drive system is greatly affected by several faults occurring on switching elements. A faulty switch in the inverter can potentially lead to more losses, extensive downtime and reduced reliability. In this paper, a novel fault identification and reconfiguration process is proposed by using discrete wavelet transform and auxiliary switching cells. Here, the discrete wavelet transform exploits a multiresolution analysis with a feature extraction methodology for fault identification and subsequently for reconfiguration. For increasing the reliability, auxiliary switching cells are integrated to replace faulty cells in a proposed reduced-switch 5-level multilevel inverter topology. The novel reconfiguration scheme compensates open circuit and short circuit faults. The complexity of the proposed system is lower relative to existing methods. This proposed technique effectively identifies and classifies faults using the multiresolution analysis. Furthermore, the measured current and voltage values during fault reconfiguration are close to those under healthy conditions. The performance is verified using the MATLAB/Simulink platform and a hardware model.
\end{abstract}

Keywords: multilevel inverter; induction motor drive; discrete wavelet transform; multiresolution analysis; feature extraction methodology

\section{Introduction}

In the past few decades, inverter-based induction motor drives have reached very high levels of performance, covering many industrial applications. At present, the multilevel inverter fed induction motor drive (MIMD) system is a favored solution for variable speed drives (VSDs) [1,2]. Multilevel inverters have gained importance in the past few decades since they are suitable for high voltage and high-power applications by virtue of their ability to synthesize waveforms with improved harmonic spectrums and lower total harmonic distortions (THD). Compared to the classical square-wave or quasi-square wave inverters, the multilevel inverter has a number of advantages such as near-sinusoidal wave-shapes, low common-mode voltage, low dv/dt voltage stress, low harmonic profile, low electromagnetic interference effects, good operating efficiency, and regulation of the drive speed $[3,4]$. Various formal multilevel inverter structures are the diode-clamped multilevel inverter [5], the flying-capacitor multilevel inverter [6], and cascaded H-bridge multilevel inverter (CHB-MLI) [7]. Among these, the CHB-MLI plays a significant role in several applications, but it is restricted to low output voltage levels. With advancements in formal multilevel inverter topologies, there have been several prominent efforts to develop novel multilevel inverter structures by utilizing low switching elements. 
The reliable and safe functioning of multilevel inverter based industrial-drive systems requires monitoring of the power-electronic switches and components. If more switches are used, the probability of faults increases and fault reconfiguration becomes a prerequisite for overcoming discontinuous functioning of the entire drive system under faulty conditions. Despite new advancements in this area, faults still occur on switching components. They are classified as short-circuit (SC) faults and open-circuit (OC) faults, primarily occurring on switches, diodes and gate-drive circuits, and are the main causes of inverter failure [8,9]. An OC fault can occur for reasons such as the degradation of the inner wire and a gatesignal fault, while an SC fault can occur under certain conditions related to over-voltage and gate-signal faults. SC faults are more difficult to ameliorate due to the high currents; they lead to serious effects on the entire system and nearby elements. When the MIMD system experiences a fault, there is a need to operate continuously in order to sustain a stable functioning of components, including relays and protective circuits [10]. These protective devices may damage the MIMD, affecting the unit and increasing the economic losses. In order for the MIMD system to function continuously, detailed information on the various faults is a prerequisite. Fault diagnosis is essential for the active compensation of OC and/or SC faults using a reconfiguration methodology. Prior information is used to identify the types of faults in order to prevent the failure of the entire drive system.

Some researchers have placed an emphasis on the use of the output voltage and/or currents for fault analysis, in order develop a process for diagnosing faults. Lezana et al. proposed an analysis of faults on a multilevel inverter that contained a high switching element count. Due to the persistence of faults in multilevel inverters, a number of fault identification and diagnosis techniques have been developed [11]. Priya et al. studied the effect of a SC fault, demonstrating that it has a greater impact compared to OC faults when no protective elements are used. A number of faults have been studied and methods proposed for diagnosing and preventing or mitigating faults in order to improve the reliability of drive systems [12]. Conventional fault identification methods are the modified-slope algorithm, which measures the slope in the complex part of the $\alpha \beta$-plane [13], reference current sequences [14], and frequency domain methods based on signal-processing techniques, e.g., the fast-Fourier transform (FFT) [15] and the discrete Fourier transform (DFT) [16].

Based on the outputs of a multilevel inverter at various frequency bands, the effect of faults, fault types and fault occurrences, can be extracted by using a discrete wavelet transform (DWT) [17]. Wavelet techniques have been developed for interrogating and manipulating signals in different applications areas, including in electric vehicles, signal processing, power electronics and mechanical systems [18-20], with decomposition levels usually between 4 and 10. This paper conducts fault analyses and identification for a proposed 5-level symmetrical reduced-switch multilevel inverter (RSMLI) fed induction motor drive based on a DWT multi resolution analysis (DWT-MRA), which leverages a feature extraction methodology (FEXM). Based on the outcomes of the proposed fault identification scheme, a fault reconfiguration scheme is also developed by using auxiliary switching cells.

The measured THD values are useful for the identification of the occurrence and type of fault in traditional FFT, neutral-point-control (NPC) multilevel inverter and the proposed DWT-MRA method, but the existence of a fault in a MIMD is identified based on a THD analysis of the line current. Initially, the THD value of the healthy condition is investigated under various reconfiguration methods; thereafter, various fault conditions are investigated in detail. The characteristics obtained from healthy conditions of the reconfiguration methods are considered as reference values for the fault compensation and are compared with the performance of the proposed RSMLI fed induction motor drive under various fault cases. Over the formal reconfiguration schemes, the proposed RSMLI scheme produces favorable THD values, which imply improved power-quality features. The proposed fault mitigation scheme is validated by using MATLAB/Simulink, along with hardware results. 


\section{Materials and Methods}

\subsection{Proposed 5-Level Symmetrical RSMLI Structure under Healthy Conditions}

The novel proposed 5-level symmetrical RSMLI structure requires a total of 6 IGBT switches and $2 \mathrm{DC}$ sources (with $\mathrm{V}_{\mathrm{dc} 1}=\mathrm{V}_{\mathrm{dc} 2}$ ), powered by a front-end rectifier, followed by a DC-link capacitor. The DC-link capacitor constitutes the interface between the rectifier and RSMLI topology. In a healthy situation, 5 staircase voltage levels are attained based on a series-operation of several cells $\left(\mathrm{V}_{\mathrm{dc}}=\mathrm{Vd}_{\mathrm{c} 1}+\mathrm{V}_{\mathrm{dc} 2}\right)$, requiring only one additional switch $S_{d a}$. The switch $S_{d a}$ is activated in healthy conditions for furnishing the return path to the drive. The DC voltage input undergoes a transformation to an AC stair-case voltage through activating the switches in an appropriate manner; the 5-level voltages are $\mathrm{V}_{\mathrm{dc}}$, $2 \mathrm{~V}_{\mathrm{dc}}, 0 \mathrm{~V}_{\mathrm{dc}},-\mathrm{V}_{\mathrm{dc}}$, and $-2 \mathrm{~V}_{\mathrm{dc}}$. The 3-phase 5-level symmetric RSMLI fed induction motor drive under healthy conditions is depicted shown in Figure 1 and the switching sequences are illustrated in Table 1.

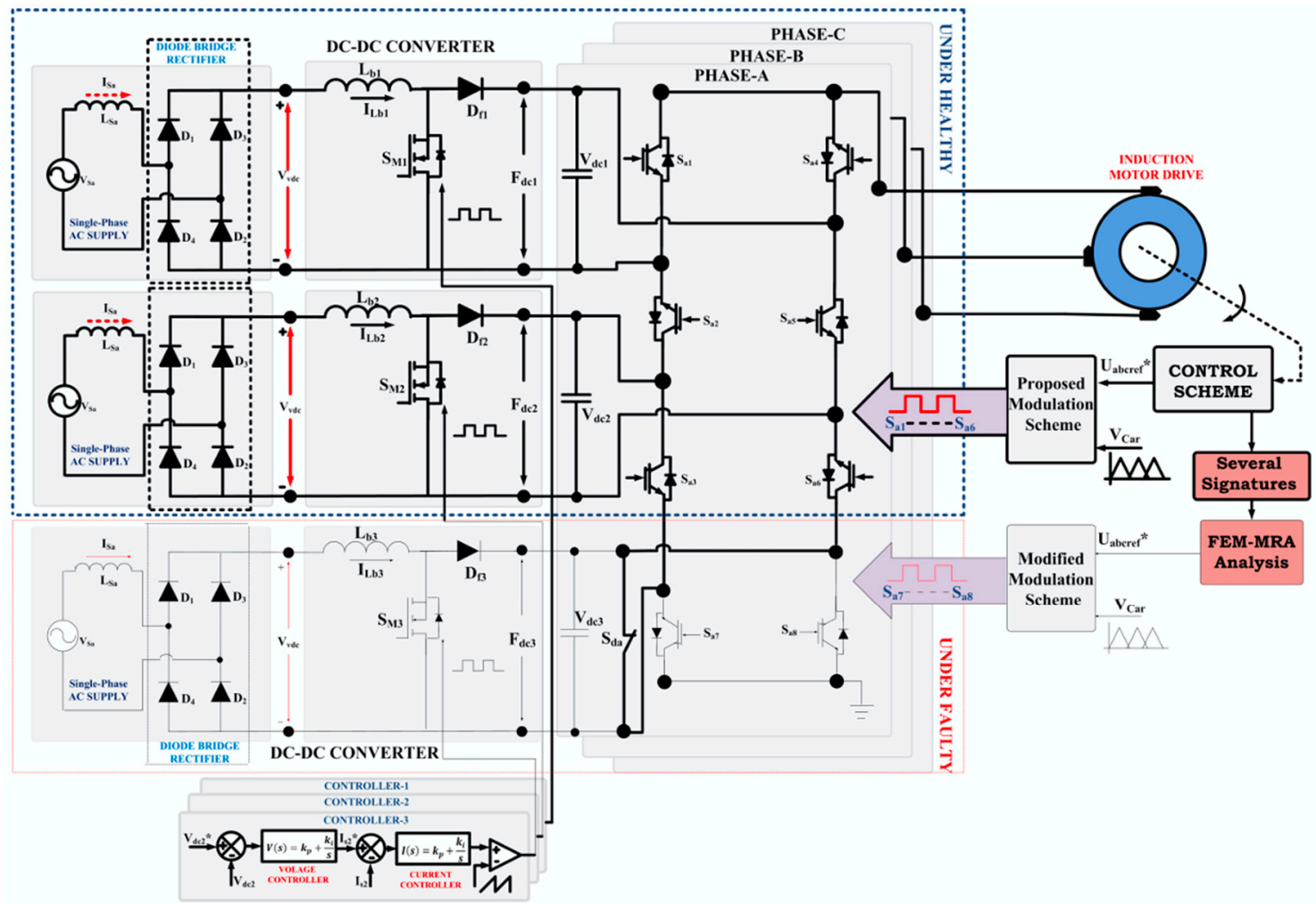

Figure 1. Schematic of the proposed three-phase 5-level symmetric RSMLI fed induction motor drive under healthy conditions.

Table 1. Sequences of switching for the 5-level symmetric RSMLI structure under healthy conditions.

\begin{tabular}{ccccccccc}
\hline Outcome Voltages & $\mathrm{S}_{\mathbf{a} 1}$ & $\mathrm{~S}_{\mathbf{a} \mathbf{2}}$ & $\mathbf{S}_{\mathbf{a} 3}$ & $\mathbf{S}_{\mathbf{a} \mathbf{}}$ & $\mathbf{S}_{\mathbf{a} 5}$ & $\mathbf{S}_{\mathbf{a} \mathbf{6}}$ & $\mathbf{S}_{\mathbf{a} 7}$ & $\mathbf{S}_{\mathbf{a} 8}$ \\
\hline $\mathrm{V}_{\mathrm{dc}}$ & $\mathrm{C}$ & $\mathrm{NC}$ & $\mathrm{NC}$ & $\mathrm{NC}$ & $\mathrm{C}$ & $\mathrm{C}$ & - & - \\
$2 \mathrm{~V}_{\mathrm{dc}}$ & $\mathrm{C}$ & $\mathrm{NC}$ & $\mathrm{C}$ & $\mathrm{NC}$ & $\mathrm{C}$ & $\mathrm{NC}$ & - & - \\
$-\mathrm{V}_{\mathrm{dc}}$ & $\mathrm{NC}$ & $\mathrm{C}$ & $\mathrm{C}$ & $\mathrm{C}$ & $\mathrm{NC}$ & $\mathrm{NC}$ & - & - \\
$-2 \mathrm{~V}_{\mathrm{dc}}$ & $\mathrm{NC}$ & $\mathrm{C}$ & $\mathrm{NC}$ & $\mathrm{C}$ & $\mathrm{NC}$ & $\mathrm{C}$ & - & - \\
$0 \mathrm{~V}_{\mathrm{dc}}$ & $\mathrm{C}$ & $\mathrm{C}$ & $\mathrm{C}$ & $\mathrm{NC}$ & $\mathrm{NC}$ & $\mathrm{NC}$ & - & - \\
\hline
\end{tabular}

Pulse-width modulation (PWM) is frequently used for generating feasible switching patterns and is used in the proposed RSMLI structure in the form of a multicarrier pulsewidth modulation scheme [21-23]. PWM regulates the pulse widths, resulting in an output voltage to control the $\mathrm{dv} / \mathrm{dt}$ stress, harmonic shifting, and minimize losses. It needs a reference signal that is sinusoidal and a number of triangular carrier signals in order to generate switching patterns. The main parameter is the modulation index $\left(m_{\text {in }}\right)$, which is 
differentiated on the basis of a sinusoidal reference amplitude $\left(A_{r}\right)$ and the amplitudes of triangular carrier signals $\left(A_{\mathcal{C}}\right)$, taking values in $(0,1)$.

$$
m_{\text {in }}=\frac{A_{r}}{A_{c}}\left(m_{\text {in }} \leq 1\right)
$$

The output voltage $\left(V_{o}\right)$ waveform magnitude depends on the voltage of the input DC link $\left(\mathrm{V}_{\mathrm{dc}}\right)$ together with the modulation index $\left(m_{i n}\right)$.

$$
V_{o}=m_{\text {in }} \mathrm{V}_{\mathrm{dc}}
$$

The multicarrier sinusoidal PWM method consists of a reference signal in each phase $\mathrm{U}_{\text {aref }}{ }^{*}, \mathrm{U}_{\text {bref }}{ }^{*} \mathrm{U}_{\text {cref }}{ }^{*}$, which are contrasted with dual carrier signals $\left(\mathrm{V}_{\text {car1 }}, \mathrm{V}_{\text {car2 } 2}\right)$. The carriers possess equal (high) frequency of switching with small deviations in the magnitudes of the peaks and the vertical displacements. The reference and carrier signals are compared in order to generate the switching states A and B. The latter are controlled using a further pulse generation sequence $C$. Equation (3) defines the optimal pulse generation to the switches and Figure 2 depicts the switching pattern for the RSMLI.

$$
\begin{gathered}
S a 1=\bar{A} C+\bar{C} \\
S a 2=C \\
S a 3=\bar{B} C+\overline{A C}+B \bar{C} \\
S b 1=A C \\
S b 2=\bar{C} A \\
S b 3=B
\end{gathered}
$$

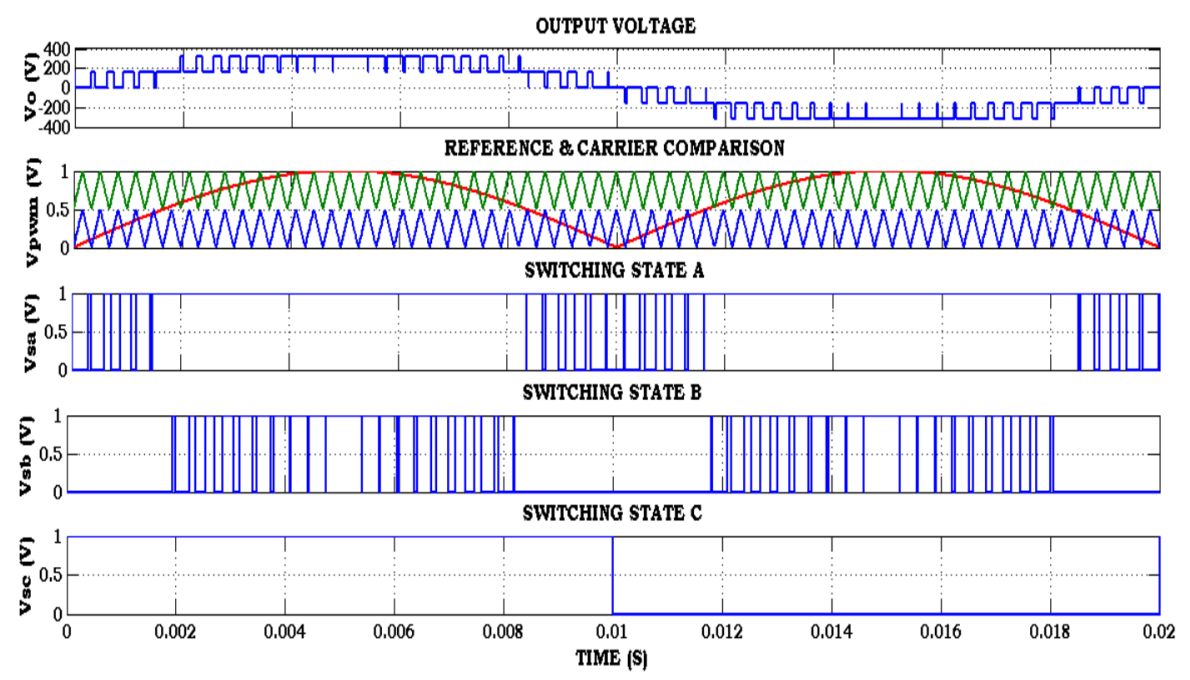

Figure 2. Simplified switching pattern. ${ }^{*} \mathrm{C}$-conduction, NC-nonconduction.

\subsection{Proposed 5-Level Symmetrical RSMLI Structure under Faulty Conditions}

The open-circuit (OC) and short-circuit (SC) faults are those most frequently encountered in multilevel inverter structures, occurring in switches and/or gate-drive circuits. These fault events lead to malfunctioning of the drive system due to extreme thermal and electrical stress experienced by nearby elements. The most systematic faults in the proposed RSMLI are gate-open circuit (GOC) faults and gate-short circuit (GSC) faults, depicted in Figure 3. In these configurations the switches $S_{a 7}$ and $S_{a 8}$ are in an idle state for a healthy state and are operational in a faulty state. Figure 3a represents a GOC-fault occurring in the phase A related to switch $S_{a 5}$ of the RSMLI. 

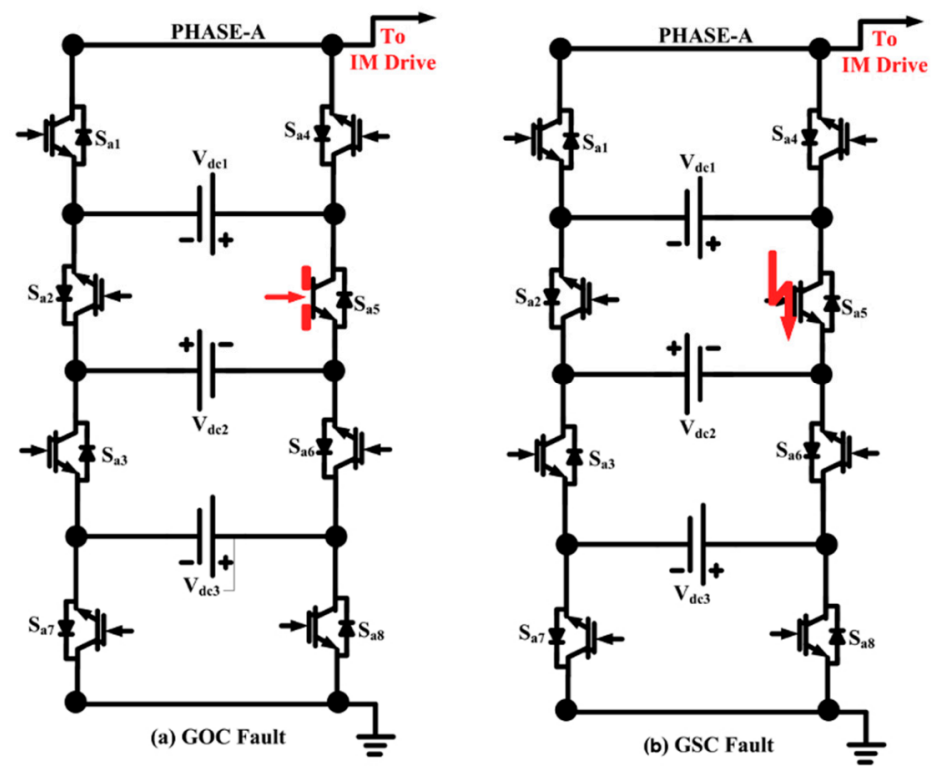

Figure 3. (a) Gate-open and (b) gate-short circuit fault states.

During a fault, it is not possible to transfer energy to the induction motor (IM) drive for continuous operation since the path of current flow becomes unbalanced, which impacts the drive speed and torque, therefore degrading its performance. Figure $3 \mathrm{~b}$ depicts a phase-A GSC fault for the switch $\mathrm{S}_{\mathrm{a} 5}$ of the RSMLI by generating a short circuit related to the switch gate-pulse signal. During this fault, there is a possibility of a high unbalanced current to the IM drive, which affects the magnitude of current in the positive region, again degrading the performance of the IM drive. The fault analysis is the same for other types of faults, such as faults on switches and diodes.

\subsection{Fault Identification Using a Discrete Wavelet Transform (DWT) Analysis}

The wavelet transform (WT) method was developed as a replacement for the shorttime Fourier transform (STFT), which uses fixed-width windowing functions. In the WT method, the width of the window is changed as the transform is computed for each spectral component [24,25]. This multiresolution analysis (MRA) allows for the identification of abrupt variations in electrical parameters such as voltage, current and frequency [17]. Wavelets are localized in both the time and frequency domains, while Fourier transforms are only localized in the frequency domain. The STFT overcomes this limitation partly, but the fixed-width windows lead to a tradeoff between time and frequency resolution. WTs offer greater time and frequency localization and are better for distinguishing important signatures from signals that have high-frequency disturbances that are short-lived, and superimposed on low-frequency signals.

A continuous wavelet transform (CWT) of the signal $x(t)$ is defined in terms of a mother wavelet $\psi(t)$. The mother wavelet is able to the translated and dilated discretely, which generates an orthonormal basis $\psi_{i, j}(t)$, where $i . j$ are integers for expressing a signal $x(t)$. The coefficients of the signal in this basis define the DWT. MRA, also called the fast wavelet transform (FWT), is a computationally efficient method to perform DWT [26]. This DWT-MRA analysis decomposes the original signal into low- and high-frequency components termed approximations and details, respectively, with divergent scales/levels of resolution. At every level, the approximations are acquired by a convolution signal with a low-pass filter and the details are obtained by the convolution of the signal with a high-pass filter, followed by a dyadic decimation process in both cases.

The procedure begins with evaluating the discrete form of the signal $x[n]$, which has a length $\mathrm{N}$ passed through digital low-pass and high-pass filters, $g[n]$ and $h[n]$. The outcomes from a low-pass filter are the $\mathrm{N}$ approximation coefficients $a^{1}[n]$, while the high-pass filter produces the detail coefficients $d^{1}[n]$; this is the first level of the MRA [27-29]. These 
coefficients are employed as the inputs for a second set of wavelet filters, with sampling by dual functionality. The filters in this level of resolution produce approximation/detail coefficients each of length $\mathrm{N} / 2$. This decomposition process is repeatedly applied up to the highest-level L (Figure 4), which enhances the resolution in terms of frequency of the discrete signal. A level 9 wavelet decomposition was utilized in this paper, with the $l$-th level defined by

$$
a^{l}[n]=\sum_{k=0}^{N / 2^{l-1}-1} g[k] a^{l-1}[2 n-k], \quad d^{l}[n]=\sum_{k=0}^{N / 2^{l-1}-1} h[k] a^{l-1}[2 n-k]
$$

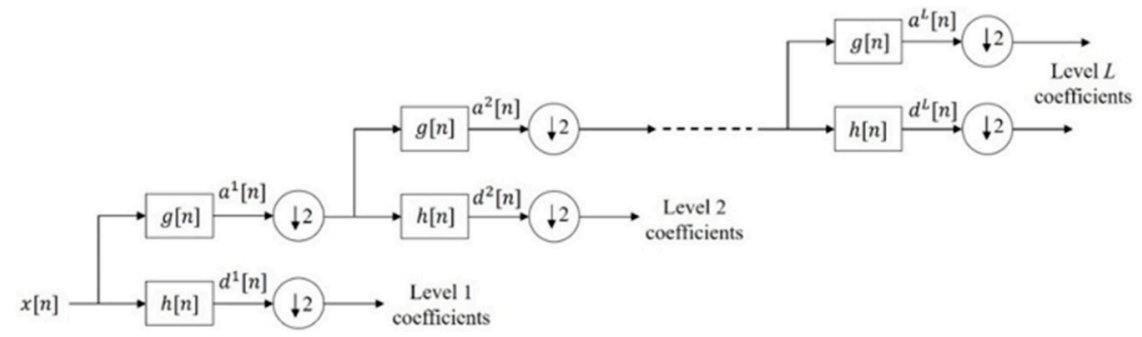

Figure 4. Decomposition process for the discrete signal in DWT.

A level of 9 ensures that there is sufficient information to form reliable statistics of the coefficients in the presence of noise, while not leading to excessive computational costs. The Haar mother wavelet was selected based on the correlation coefficient value. It is worth mentioning that the computational costs of FWT-MRA is $\mathrm{O}(N)$ compared to $\mathrm{O}$ (N $\log 2(N))$ for the FFT.

In general, the fault in the MIMD system is identified by the gradient of the line current. This is not suitable, however, for dynamic conditions. For these cases, a wavelet-based feature extraction methodology (FEXM) [28] can be used effectively for detecting faults using a decomposition feature rate $\left(D_{f r}\right)$. The $D_{f r}$ value is determined from a FEXM on the line currents for both healthy and faulty states by first performing a DWT analysis to obtain high-frequency information on the currents in the form of the detail coefficients $d^{l}[n]$. Several signatures are then calculated, such as the mean $\overline{d^{l}}=\frac{1}{N / 2^{l-1}-1} \sum_{n} d^{l}[n]$, median, standard deviation $\sigma\left(d_{l}\right)=\frac{1}{N / 2^{l-1}-2} \sum_{n}\left(d^{l}[n]-\overline{d^{l}}\right)^{2}$ and median absolute deviation (Mad), which is the median of $\left|\overline{d^{l}}-d^{l}[n]\right|$, of these coefficients, where $d_{i}, i=1, \ldots, L$, denotes the decomposition level. From the standard deviations at different levels of decomposition, the $D_{f r}$ is obtained as follows.

$$
D_{f r}=\frac{\sigma\left(d_{2}\right)+\sigma\left(d_{3}\right)+\ldots+\sigma\left(d_{L-1}\right)}{(L-2) \overline{\sigma_{h}}}
$$

In which $\overline{\sigma_{h}}=(L-2)^{-1} \sum_{i=2}^{L-1} \sigma\left(d_{i}\right)$ under healthy conditions. The standard deviations of the wavelets coefficients have been used extensively for fault detection in various electrical and mechanical systems [30-32]. It can often be the case that the standard deviations for the lowest and highest-level features do not vary significantly from the healthy values [31]. Thus, the summation in (5) discards these values.

Faults can be identified by observing the value of $D_{f r}$ under both healthy and faulty conditions. If $D_{f r}$ is less than a certain threshold value (the value at the healthy condition within a tolerance determined from a prior analysis), then a fault is identified. Nevertheless, $D_{f r}$ is unable to classify the type of fault, so further analysis is required. The average Mad values of the $d_{2}$ to $d_{8}$ detail coefficients under healthy and different faulty conditions at the different decomposition levels is used to classify the type of fault. These average $M_{a d}$ values in each phase are compared with a threshold value obtained from a prior analysis 
under faulty and healthy conditions to clearly classify the fault type. If $\mathrm{M}_{\mathrm{ad}}$ is lower than a threshold, any fault is labelled an OC fault, and it is otherwise classified as a SC fault.

\subsection{Fault-Reconfiguration Technique Using Auxiliary Switching Cells}

The novel reconfiguration technique of the proposed 5-level symmetrical RSMLI structure in this article is based on a fault reconfiguration technique using back-to-back switches in [30-33]. It requires only eight IGBT switches in the overall configuration; three equal DC sources $\left(\mathrm{V}_{\mathrm{dc} 1}=\mathrm{V}_{\mathrm{dc} 2}=\mathrm{V}_{\mathrm{dc} 3}\right)$, powered by a front-end rectifier followed by a DC-link capacitor. The additional auxiliary switching cells $S_{a 7}$ and $S_{a 8}$ are incorporated under faulty conditions and are otherwise turned off. For example, if $S_{a}$ in the module fails due to any type of fault then antiparallel thyristors across the switches are activated to continue operation with auxiliary switches. Therefore, when a fault occurs in any switch of the upper and/or lower module, the proposed fault identification scheme activates the auxiliary switch cell through a control unit. During a fault occurrence, the additional fault-tolerance switch $S_{\mathrm{da}}$ is turned off and the corresponding five staircase voltage levels are attained. The switch $S_{\mathrm{da}}$ is nonconducting under faulty conditions due to the energy provided by the auxiliary cells. Figure 5 shows a schematic of the proposed reconfiguration technique under faulty conditions. It is noted that the input DC voltage undergoes a transformation to an AC staircase voltage with proper switching sequences, as shown in Table 2. The corresponding 5-level voltages are $\mathrm{V}_{\mathrm{dc}}, 2 \mathrm{~V}_{\mathrm{dc}}, 0 \mathrm{~V}_{\mathrm{dc}},-\mathrm{V}_{\mathrm{dc}}$, and $-2 \mathrm{~V}_{\mathrm{dc}}$.

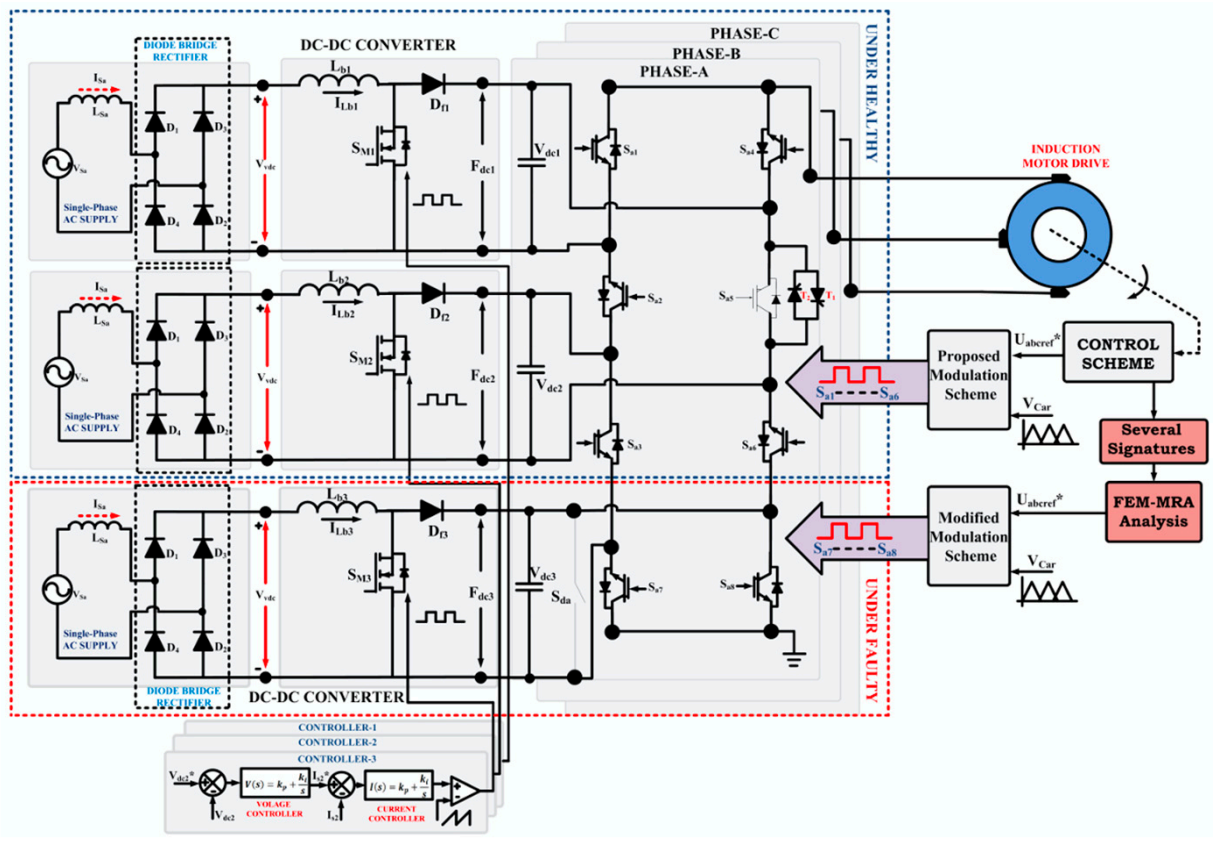

Figure 5. Schematic of the proposed fault-reconfiguration technique in a three-phase 5-level symmetric RSMLI fed induction motor drive system under faulty conditions.

Table 2. Novel reconfiguration switching sequences of proposed 5-level symmetric RSMLI structure in faulty conditions.

\begin{tabular}{ccccccccc}
\hline Outcome Voltages & $\mathrm{S}_{\mathrm{a} 1}$ & $\mathrm{~S}_{\mathrm{a} 2}$ & $\mathrm{~S}_{\mathrm{a} 3}$ & $\mathrm{~S}_{\mathrm{a} 4}$ & $\mathrm{~S}_{\mathrm{a} 5}$ & $\mathrm{~S}_{\mathrm{a} 6}$ & $\mathrm{~S}_{\mathrm{a} 7}$ & $\mathrm{~S}_{\mathrm{a} 8}$ \\
\hline $\mathrm{V}_{\mathrm{dc}}$ & $\mathrm{NC}$ & $\mathrm{C}$ & $\mathrm{C}$ & $\mathrm{C}$ & - & $\mathrm{NC}$ & $\mathrm{C}$ & $\mathrm{NC}$ \\
$2 \mathrm{~V}_{\mathrm{dc}}$ & $\mathrm{NC}$ & $\mathrm{C}$ & $\mathrm{NC}$ & $\mathrm{C}$ & - & $\mathrm{C}$ & $\mathrm{NC}$ & $\mathrm{C}$ \\
$-\mathrm{V}_{\mathrm{dc}}$ & $\mathrm{C}$ & $\mathrm{C}$ & $\mathrm{C}$ & $\mathrm{NC}$ & - & $\mathrm{NC}$ & $\mathrm{NC}$ & $\mathrm{C}$ \\
$-2 \mathrm{~V}_{\mathrm{dc}}$ & $\mathrm{NC}$ & $\mathrm{NC}$ & $\mathrm{C}$ & $\mathrm{C}$ & - & $\mathrm{NC}$ & $\mathrm{NC}$ & $\mathrm{C}$ \\
$0 \mathrm{~V}_{\mathrm{dc}}$ & $\mathrm{C}$ & $\mathrm{C}$ & $\mathrm{C}$ & $\mathrm{NC}$ & - & $\mathrm{NC}$ & $\mathrm{C}$ & $\mathrm{NC}$ \\
\hline
\end{tabular}

C-conduction, NC-nonconduction. 
The response of the multilevel inverter can be analyzed using DWT-FEXM signatures under healthy and faulty conditions based on the $D_{f r}$ and the Mad value. The average Mad for each phase is compared with threshold values to classify the fault type. After identification of the fault type, the faulty switch is turned off by using the thyristors, activating the auxiliary switching cell in the respective phase. Furthermore, if the $D_{f r}$ value is less than the threshold value after activation of the auxiliary switch, the process is continued until no fault is detected in the relevant phase of the RSMLI system, the flow-chart of the proposed fault reconfiguration technique is illustrated in Figure 6.

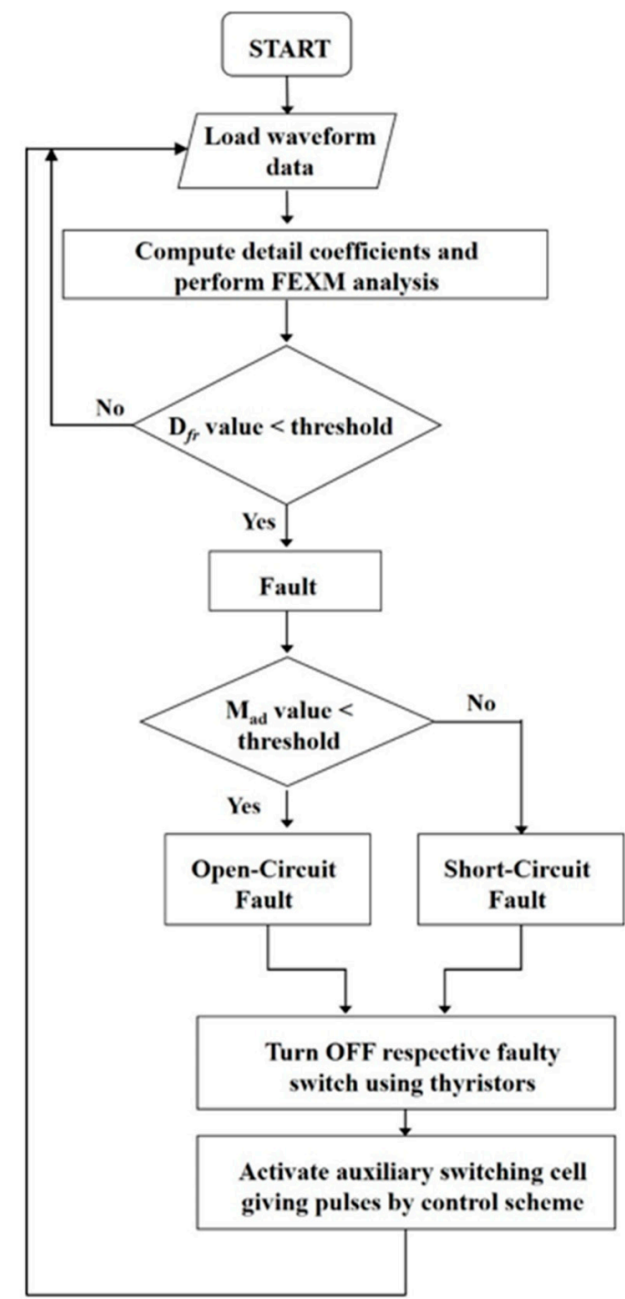

Figure 6. Flow chart of the fault reconfiguration technique.

\section{Results}

\subsection{Simulation Results}

The RSMLI system is typically operated by an AC source in single phase with an ACDC front end and a DC-DC converter for constant DC-link voltages to drive the multilevel inverter. In this context, a commanding signal is used to construct the GOC and GSC faults in a RSMLI system; it is set as " 0 " for OC faults and " 1 " for SC faults. The DWT-MRA analysis was performed with the MATLAB/Simulink tool. The analysis identifies the faulty switch and faulty phase by measuring the median, mean, standard deviation, and other features of the DWT coefficients using a FEXM. The operating specifications of the proposed RSMLI system are presented in Table 3. 
Table 3. System specifications.

\begin{tabular}{cc}
\hline Parameters & Values \\
\hline AC Source & Vsa $=230 \mathrm{~V}, \mathrm{~F}=50 \mathrm{~Hz}$ \\
Inductors & $\mathrm{Lb} 1=\mathrm{Lb} 2=\mathrm{Lb} 3=1.2 \mathrm{mH}$ \\
DC-Link Capacitor & $\mathrm{Cdc}=690 \mu \mathrm{F}$, \\
Switching Frequency & $\mathrm{Vdc} 1=\mathrm{Vdc} 2=\mathrm{Vdc} 3=200 \mathrm{~V}$ \\
Induction Motor & $\mathrm{Fs}=3050 \mathrm{~Hz}$ \\
\hline
\end{tabular}

\subsubsection{Case A: Evaluation for a Healthy State}

Figure 7 shows the line currents, the stator current, the rotor speed, and the electromagnetic torque under healthy conditions. The line currents $\left(\mathrm{I}_{\mathrm{Labc}}\right)$ are constant at $43.1 \mathrm{~A}$ and with a phase displacement of $120^{\circ}$. The stator current $\left(\mathrm{I}_{\mathrm{sa}}\right)$ is maintained sinusoidal with a value of $58 \mathrm{~A}$ at the start and $43.1 \mathrm{~A}$ under steady-state. The induction motor speed $\left(\mathrm{N}_{\mathrm{r}}\right)$ reaches a steady-state plateau at $1360 \mathrm{rpm}$ within $0.1 \mathrm{~s}$. The electromagnetic torque $\left(\mathrm{T}_{\mathrm{e}}\right)$ of the induction motor rises to around $45 \mathrm{~N}$-m before settling on the rated mechanical torque at steady-state.
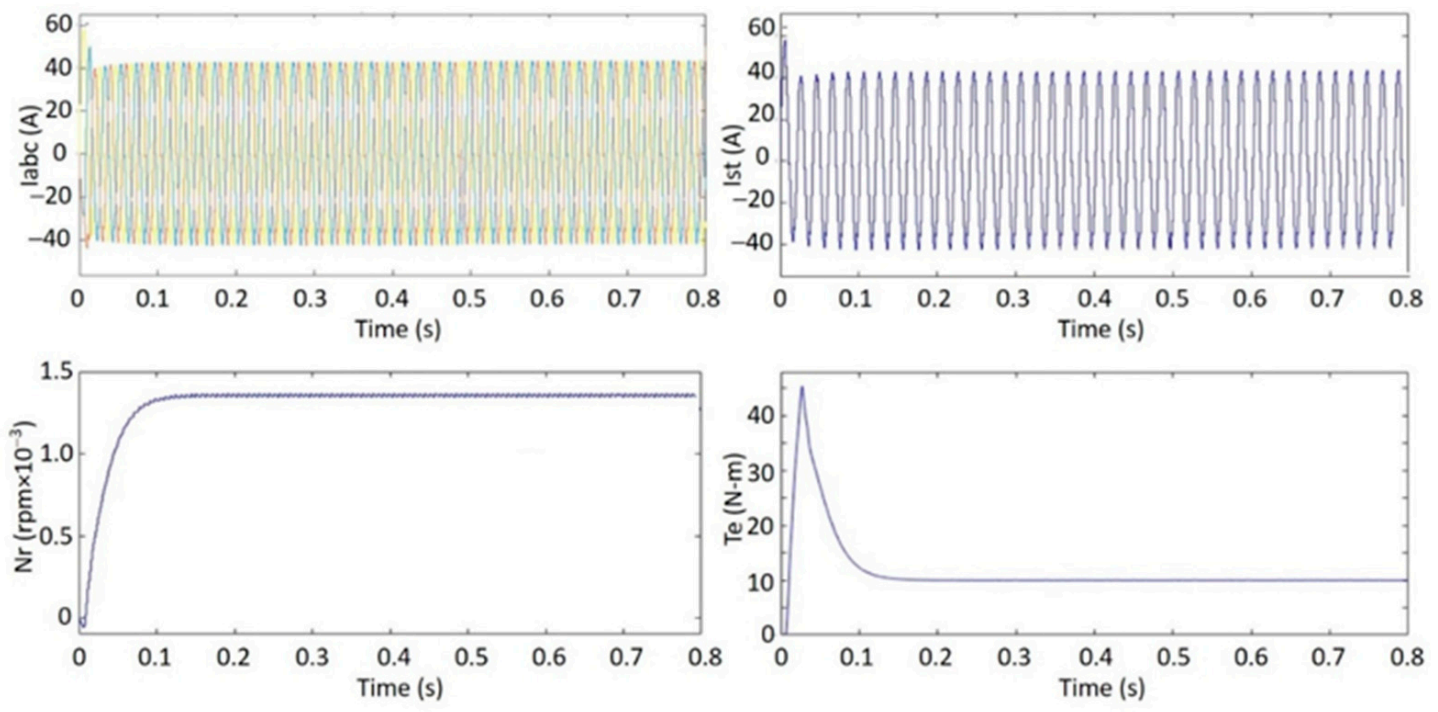

Figure 7. Simulation results under healthy conditions.

\subsubsection{Case B: Performance during GOC Fault and Fault Reconfiguration States}

The motor drive performance during reconfiguration was evaluated during a GOC fault and is shown in Figure 8. The GOC fault occurs at $t=0.5 \mathrm{~s}$ by opening the gate-pulse of switch $S_{a 5}$. To compensate the GOC fault, the reconfiguration technique is initiated at $t=0.6 \mathrm{~s}$ by activating the switches of the auxiliary switching cell. By virtue of the openfault, switch $S_{a 5}$ is considered a gate-pulse failure affecting certain characteristics of the multilevel inverter and induction motor drive. Under prefault conditions before $t=0.5 \mathrm{~s}$, $\mathrm{I}_{\text {Labc }}$ remains constant at 43.1 A with a phase displacement of $120^{\circ}, \mathrm{N}_{\mathrm{r}}$ is maintained constant at $1360 \mathrm{rpm}$ and $\mathrm{T}_{\mathrm{e}}$ is around $10 \mathrm{~N}-\mathrm{m}$. 

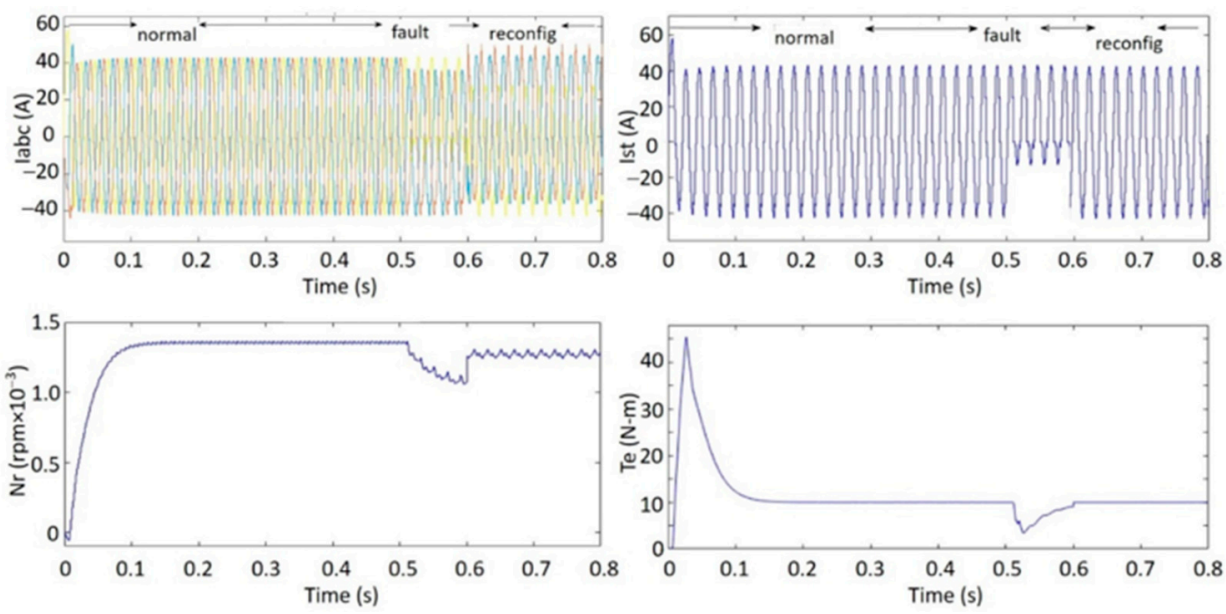

Figure 8. Simulation results during a GOC fault and the fault reconfiguration technique.

In the period $0.5 \mathrm{~s}<t<0.6 \mathrm{~s}$ when the fault occurs, the line current of the faulty phase decreases and is unbalanced at $12 \mathrm{~A}$ in the negative half-cycle. The rotor speed (Nr) fluctuates and reduces to $1050 \mathrm{rpm}$, while the electromagnetic torque fluctuates and decreases to $3.5 \mathrm{~N}-\mathrm{m}$. During fault reconfiguration, initiated at $t=0.6 \mathrm{~s}$, the line current of the faulty phase recovers to a value of almost $41 \mathrm{~A}$ and a phase displacement of $120^{\circ}$. The rotor speed $(\mathrm{Nr})$ adopts a constant value of $1360 \mathrm{rpm}$ and the electromagnetic torque $(\mathrm{Te})$ of the induction motor returns to almost $10 \mathrm{~N}-\mathrm{m}$.

\subsubsection{Case C: Performance during GSC Fault and Fault Reconfiguration States}

Under GSC fault conditions, the performance is shown in Figure 9. The fault begins at $0.5 \mathrm{~s}$ by the misfiring of the gate-pulse by the addition of the step response to the switching pattern of $\mathrm{S}_{\mathrm{a} 5}$. The fault reconfiguration technique is initiated at $t=0.6 \mathrm{~s}$. The prefault conditions before $t=0.5 \mathrm{~s}$ are as in cases $\mathrm{A}$ and $\mathrm{B}$.
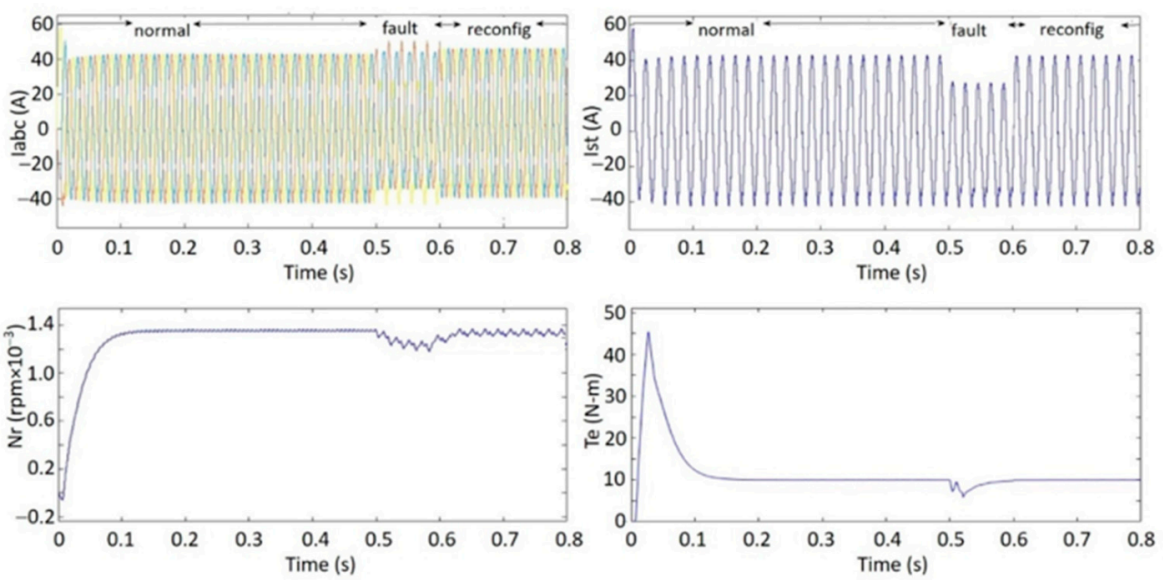

Figure 9. Simulation results during GSC fault and fault reconfiguration.

During the fault $0.5 \mathrm{~s}<t<0.6 \mathrm{~s}$, the line current of the faulty phase decreases and becomes unbalanced at $27.5 \mathrm{~A}$ in the positive half-cycle, while in the other phases there is a small decrease. $\mathrm{N}_{\mathrm{r}}$ fluctuates and reduces to $1230 \mathrm{rpm}$, while $\mathrm{T}_{\mathrm{e}}$ fluctuates and decreases to $6 \mathrm{~N}-\mathrm{m}$, returning to the rated torque within $0.15 \mathrm{~s}$. The maximum fault detection time is $50 \%$ of the switching period, while detection is accurate, fast and straightforward. After fault reconfiguration the line current of the faulty phase is maintained as balanced with a value of $41 \mathrm{~A}$ and a $120^{\circ}$ phase displacement. $\mathrm{N}_{\mathrm{r}}$ is maintained at $1360 \mathrm{rpm}$ and $\mathrm{T}_{\mathrm{e}}$ is nearly $10 \mathrm{~N}$-m. 
Following DWT-MRA on the line currents, the FEXM signatures of the detail coefficients under healthy, GOC/GSC fault, and fault reconfiguration conditions are provided in Table 4, with respect to the level of decomposition. Included are the mean, median, standard deviation and $\mathrm{M}_{\mathrm{ad}}$. The DAQ-9227 current acquisition card measures the values for a specified number of levels directly from a hardware-interaction system. The data are exported to an Excel sheet and then imported to a mat-file program, which generates the respective wave-shape signatures.

Table 4. Signatures measured under different conditions with respect to the level of decomposition.

\begin{tabular}{|c|c|c|c|c|c|c|c|c|c|}
\hline & \multicolumn{9}{|c|}{ Level of Decomposition } \\
\hline & $d_{1}$ & $d_{2}$ & $d_{3}$ & $d_{4}$ & $d_{5}$ & $d_{6}$ & $d_{7}$ & $d_{8}$ & $d_{9}$ \\
\hline \multicolumn{10}{|c|}{ Under healthy conditions } \\
\hline Mean & -0.46 & -0.52 & -0.29 & -0.93 & -0.53 & -0.82 & -0.38 & -0.29 & -0.33 \\
\hline Median & -3.59 & -3.36 & -2.72 & -3.82 & -3.12 & -3.59 & -3.12 & -3.13 & -2.72 \\
\hline Standard Deviation & 30.06 & 30.11 & 30.18 & 29.96 & 30.12 & 29.97 & 30.15 & 30.14 & 30.15 \\
\hline $\begin{array}{l}\text { Median Absolute } \\
\text { Deviation }\end{array}$ & 29.97 & 30.15 & 30.73 & 29.74 & 30.37 & 29.97 & 30.45 & 30.45 & 30.73 \\
\hline \multicolumn{10}{|c|}{ Under GOC faulty conditions } \\
\hline Mean & 11.84 & 11.43 & 11.64 & 11.74 & 11.56 & 11.35 & 12.06 & 11.74 & 11.35 \\
\hline Median & 0.49 & 0.04 & 0.05 & 0.05 & 0.04 & 0.04 & 0.75 & 0.05 & 0.04 \\
\hline Standard Deviation & 19.38 & 19.42 & 19.36 & 19.26 & 19.33 & 19.32 & 19.43 & 19.26 & 19.32 \\
\hline $\begin{array}{l}\text { Median Absolute } \\
\text { Deviation }\end{array}$ & 11.63 & 11.12 & 11.17 & 10.98 & 11.12 & 10.94 & 11.82 & 10.98 & 10.94 \\
\hline \multicolumn{10}{|c|}{ Under GSC faulty conditions } \\
\hline Mean & -9.17 & -8.83 & -9.01 & -10.09 & -9.62 & -10.19 & -8.91 & -9.48 & -9.19 \\
\hline Median & -13.4 & -12.95 & -12.95 & -13.69 & -13.57 & -13.81 & -13.11 & -13.52 & -13.28 \\
\hline Standard Deviation & 24.44 & 24.61 & 24.61 & 24.61 & 24.51 & 24.58 & 24.42 & 24.51 & 24.65 \\
\hline $\begin{array}{c}\text { Median Absolute } \\
\text { Deviation }\end{array}$ & 21.71 & 22.08 & 22.07 & 21.62 & 21.61 & 21.45 & 21.78 & 21.64 & 21.92 \\
\hline \multicolumn{10}{|c|}{ Under GOC fault reconfiguration conditions } \\
\hline Mean & 4.85 & 4.61 & 4.64 & 4.54 & 4.88 & 4.56 & 4.71 & 4.57 & 4.65 \\
\hline Median & 10.23 & 10.12 & 10.07 & 9.92 & 10.25 & 9.93 & 10.1 & 9.83 & 10.01 \\
\hline Standard Deviation & 28.19 & 28.15 & 28.22 & 28.26 & 28.15 & 28.21 & 28.16 & 28.11 & 28.13 \\
\hline $\begin{array}{c}\text { Median Absolute } \\
\text { Deviation }\end{array}$ & 24.87 & 25.02 & 24.99 & 25.16 & 24.81 & 25.12 & 24.95 & 25.21 & 25.02 \\
\hline \multicolumn{10}{|c|}{ Under GSC fault reconfiguration conditions } \\
\hline Mean & -5.12 & -5.22 & -5.21 & -5.31 & -5.13 & -5.25 & -5.41 & -5.22 & -5.41 \\
\hline Median & -10.1 & -10.4 & -10.5 & -10.6 & -10.1 & -10.5 & -10.7 & -10.4 & -10.7 \\
\hline Standard Deviation & 27.77 & 27.79 & 27.84 & 27.81 & 27.82 & 27.85 & 27.79 & 27.87 & 27.79 \\
\hline $\begin{array}{l}\text { Median Absolute } \\
\text { Deviation }\end{array}$ & 24.93 & 24.80 & 24.75 & 24.64 & 24.97 & 24.75 & 24.64 & 24.80 & 24.64 \\
\hline
\end{tabular}

Under healthy conditions, the maximum mean takes on a small negative value of -0.93 at level $d_{4}$. The maximum median is also slightly negative, -3.82 at level $d_{4}$. The highest value standard deviation occurs at $d_{3}$ (30.18). The maximum $\mathrm{M}_{\mathrm{ad}}$ is 30.73 , occurring at both $d_{3}$ and $d_{9}$. Table 4 shows the signatures related to the GOC fault. The maximums in the mean, median, and standard deviation are obtained at level $d_{7}$, taking values 12.06, 
0.75 and 19.43 , respectively. The maximum value of $\mathrm{M}_{\mathrm{ad}}$ is 11.82 , at level $d_{7}$. For a GSC fault, the maximum mean and median are negative with values of -10.19 and -13.81 at level $d_{6}$. The maximum standard deviation is 24.65 at level $d_{9}$, while the maximum value of $\mathrm{M}_{\mathrm{ad}}$ is 22.08 , at level $d_{2}$.

Under GOC fault reconfiguration conditions the highest mean and median are 4.88 and 10.25 (level $d_{5}$ ). The maximum in the standard deviation is 28.26 , for level $d_{4}$, while the highest $\mathrm{M}_{\mathrm{ad}}$ is 25.21 attained at level $d_{8}$. The maximums in the mean, median and standard deviation under GSC fault reconfiguration conditions are $-5.41,-10.7$, attained at levels $d_{7}$ and $d_{9}$, while the maximum standard deviation is 27.87 , at level $d_{8}$. The highest value of $\mathrm{M}_{\mathrm{ad}}$ is 24.97 , attained at level $d_{5}$. It can be seen that the statistical signatures in Table 4 have variations between states (healthy, faulty, reconfiguration conditions) that can be reliably used for fault analysis, and that the values of the signatures are close to constant from decomposition level to decomposition level. Table 5 shows that the presence of a fault and the type of the fault in the system are reliably identified by $D_{f r}$ and the average $\mathrm{Mad}_{\mathrm{ad}}$.

Table 5. Measured $D_{f r}$ values under healthy, faulty and reconfiguration conditions.

\begin{tabular}{cccccc}
\hline & \multirow{2}{*}{ Healthy } & \multicolumn{2}{c}{ Under Fault Condition } & \multicolumn{2}{c}{$\begin{array}{c}\text { Under Fault } \\
\text { Reconfiguration }\end{array}$} \\
\cline { 3 - 6 } & & GOC & GSC & GOC & GSC \\
\cline { 3 - 6 } & 1 & 0.6427 & 0.8159 & 0.9364 & 0.9250 \\
$\boldsymbol{D}_{f r}$ & 30.27 & 11.16 & 21.75 & 25.03 & 27.76 \\
\hline
\end{tabular}

In Table 5, Equation (5) is used to calculate the $D_{f r}$ values for the different states (healthy, faulty, reconfigured) from the $\mathrm{d}_{2}$ to $\mathrm{d}_{8}$ standard deviations in Table 4 . The $D_{f r}$ threshold value is taken as 0.9 for identifying the fault. Similarly, the average $M_{\text {ad }}$ values for the different states are calculated from the $d_{2}$ to $d_{8} M_{a d}$ values in Table 4 . The $M_{a d}$ threshold value for classifying the fault is taken to be 16.46 (midway between the values for the two fault types).

Table 6 compares the drawbacks of the proposed method as well as existing methods. The faulty phase leg isolation method [34] will operate only with two phases under faulty conditions, which results in unbalanced per phase conditions and a reduced peak value. The method of isolating a faulty device using fuses [35] has the drawback of requiring additional components in addition to a complex control strategy and the extra stress placed on the remaining healthy devices. In the method of isolating a faulty cell [36], healthy devices undergoing reconfiguration conditions will experience a higher voltage stress. Moreover, this method cannot be applied to different MLIs. The Active Neutral-PointClamped (ANPC) fault-tolerant inverter [37] has many drawbacks, but the main drawback is that it can only be applied to a three-level condition.

Table 6. Comparison of the proposed method with existing methods.

\begin{tabular}{|c|c|c|c|c|c|}
\hline & $\begin{array}{l}\text { Faulty Phase Leg } \\
\text { Isolation Method }\end{array}$ & $\begin{array}{l}\text { Isolating a Faulty } \\
\text { Device Using Fuses }\end{array}$ & $\begin{array}{c}\text { Faulty Cell } \\
\text { Isolation Method }\end{array}$ & $\begin{array}{c}\text { ANPC Fault- } \\
\text { Tolerant Inverter }\end{array}$ & $\begin{array}{l}\text { Proposed } \\
\text { Method }\end{array}$ \\
\hline Extra Stress on Devices & & $\checkmark$ & $\checkmark$ & & \\
\hline $\begin{array}{l}\text { Unbalanced Per-phase } \\
\text { Condition }\end{array}$ & $\checkmark$ & & & $\checkmark$ & \\
\hline Reduced Peak Value & $\checkmark$ & & & $\checkmark$ & \\
\hline $\begin{array}{c}\text { Excessive Complexity of } \\
\text { Control }\end{array}$ & & $\checkmark$ & & $\checkmark$ & \\
\hline $\begin{array}{l}\text { Excessive Add-on } \\
\text { Components }\end{array}$ & & $\checkmark$ & $\checkmark$ & & $\checkmark$ \\
\hline Not Applicable to & & & $\checkmark$ & & \\
\hline Different Inverters & & & $\checkmark$ & & \\
\hline $\begin{array}{l}\text { Not Applicable to } \\
\text { Different Levels }\end{array}$ & & & & $\checkmark$ & \\
\hline
\end{tabular}


Compared to the existing methods, the proposed method requires the most add-on components, namely for the inverter considered, which requires additional thyristors. Although the additional cost will be higher with the proposed method, the lack of other disadvantages suggest it is an attractive option, especially for applications requiring high reliability and near-normal operation.

\subsection{Experimental Results}

To validate the RSMLI topology and reconfiguration, we conducted experiments by interfacing with MATLAB/Simulink (Figure 10). A total of six Si4850BDY TrenchFET Gen IV power MOSFETs were employed. In this setup, the drain-to-source voltage was set to $80 \mathrm{~V}$ and the gate-to-source voltage was set to $\pm 20 \mathrm{~V}$, having a dissipated power of $4.5 \mathrm{~W}$ at $25{ }^{\circ} \mathrm{C}$. A CMOS 8-bit microcomputer possessing $4 \mathrm{~K}$ bytes of flash-programmable memory was employed for the design of a dSPACE DS1103 digital controller in real time. The PWM signals were generated using the dSPACE under different strategies. The required offline simulations of the gate signal generation blocks for the proposed symmetrical RSMLI using the sinusoidal PWM technique were performed with the help of SIMULINK. The SIMULINK model was compiled before being executed in real time on the dSPACE system. A "build" function in SIMULINK converts the SIMULINK model into C code, which forms the source for the real-time dSPACE system interface. The switching pulses are obtained from the input and output ports of the dSPACE system; they are sent to pulse amplifiers before application to the gates of the power MOSFETs.

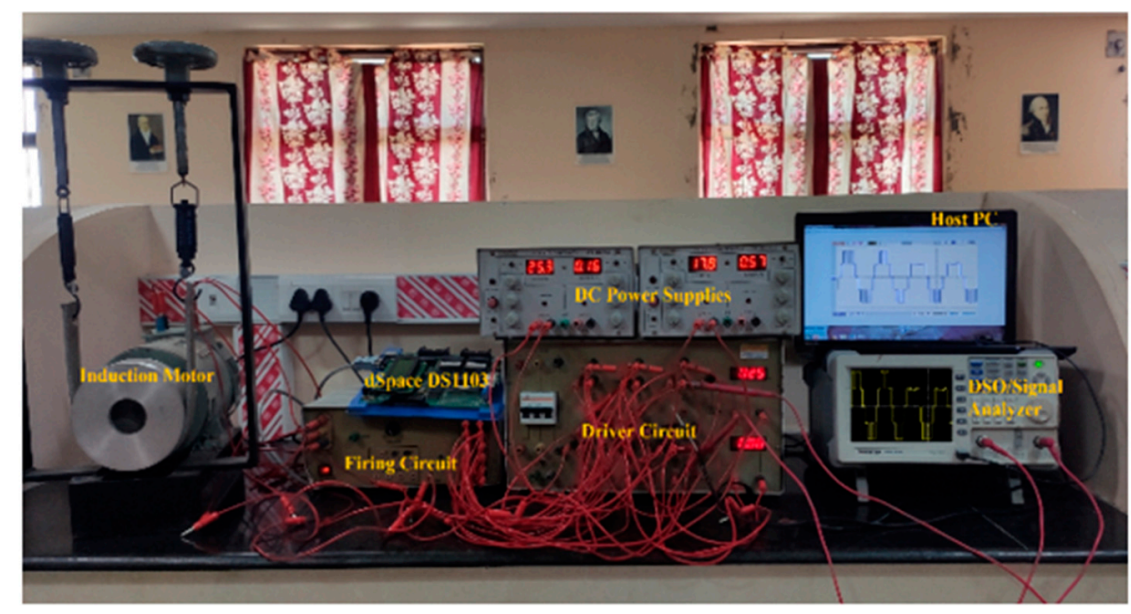

Figure 10. Hardware prototype model.

The output voltages for the healthy, faulty and reconfiguration states are shown in Figures 11-14, respectively. The staircase 5-level output voltages were generated by activating the relevant switches in the RSMI topology under the control of a frequencybased voltage pulse method. To investigate faulty conditions, an open-switch fault was initiated for switch Sa5 by the opening of its gate pulse. When the fault is initiated in Sa5, Figure $11 \mathrm{~b}$ shows that the highest voltage level is missed.

After initiating the proposed reconfiguration method, the voltage is reconfigured to the original value as shown in Figure 11c. A short-circuit fault is initiated for Sa5 by the misfiring of the gate pulse. Switch Sa5 then constitutes a malfunction of the gate-pulse, which decreases the line current (Figure 12b). The healthy and reconfigured current waveforms are depicted in Figures 12a,c, respectively. When the proposed reconfiguration method is initiated, it successfully reconfigures the failed RSMLI in a fraction of a fundamental cycle. 

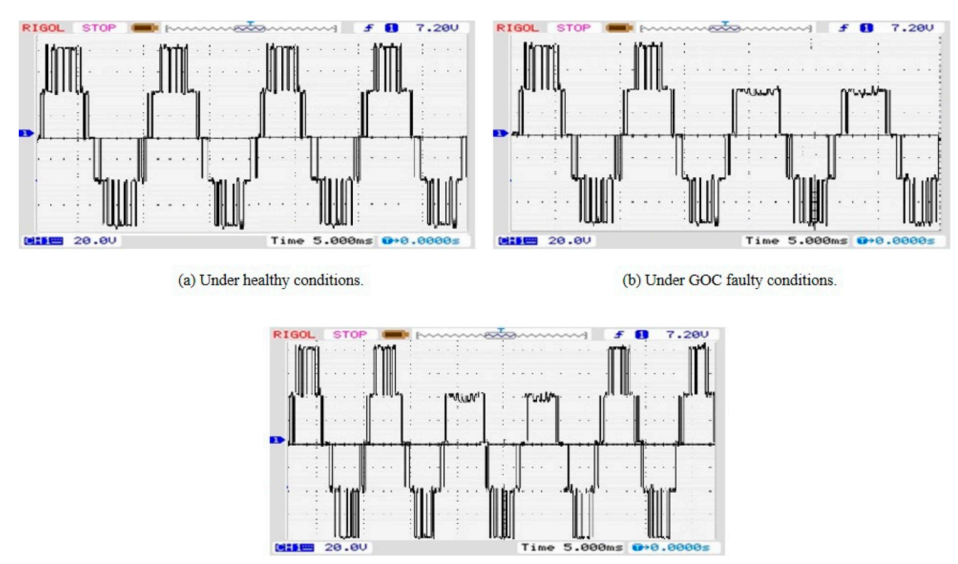

(c) Under reconfiguration conditions.

Figure 11. 5-Level output voltage under healthy, GOC faulty and reconfiguration conditions.

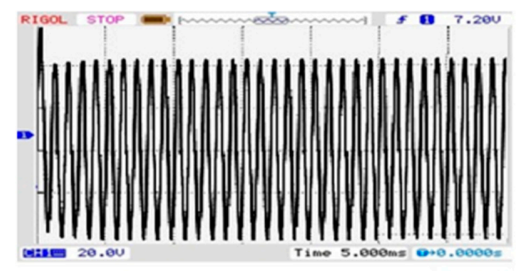

(a) Under healthy conditions

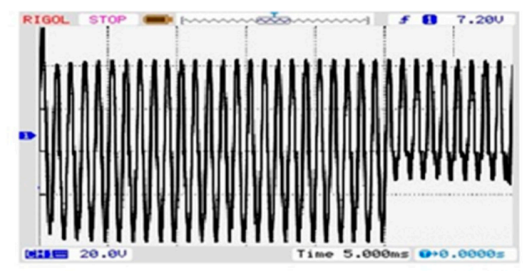

(b) Under GSC faulty conditions.

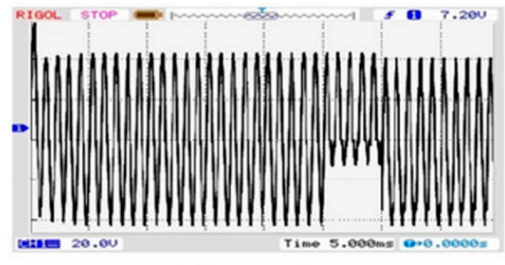

(c) Under reconfiguration conditions.

Figure 12. 5-Level output current under healthy, GSC faulty and reconfiguration conditions.

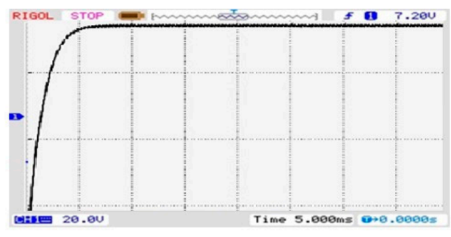

(a) Under healthy conditions.
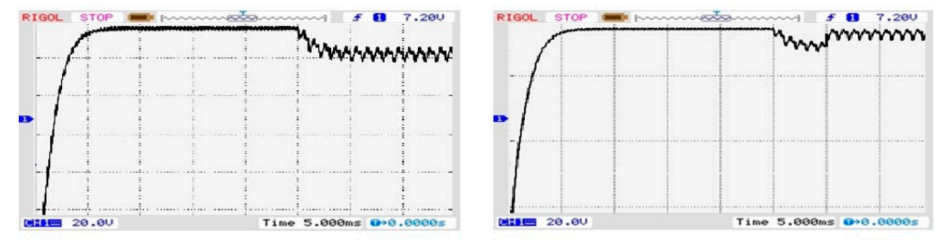

(b) Under GSC faulty conditions

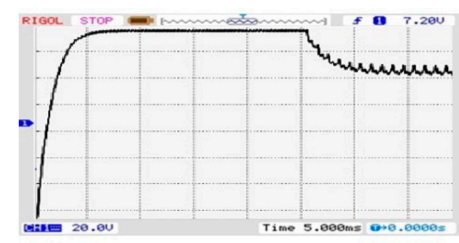

(d) Under GOC faulty conditions

(c) Under GSC reconfiguration conditions.

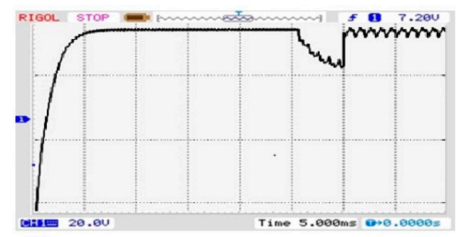

(e) Under GOC reconfiguration conditions.

Figure 13. Rotor speed of the induction motor for healthy conditions, and faulty and reconfiguration conditions. 


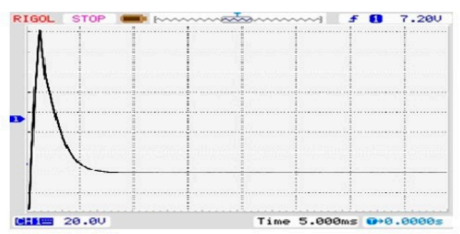

(a) Under healthy conditions.

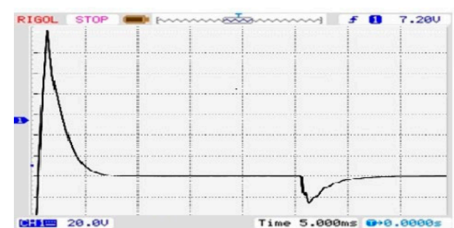

(b) Under GSC faulty conditions.

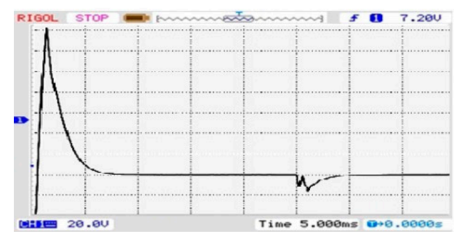

(d) Under GOC faulty conditions

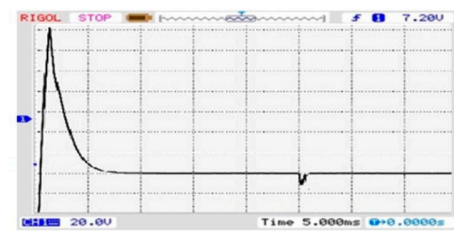

(c) Under GSC reconfiguration conditions.

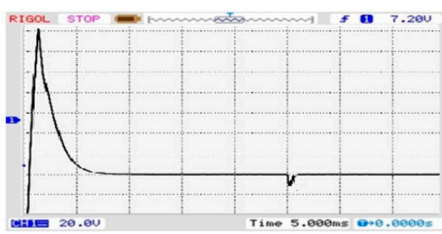

(e) Under GOC reconfiguration conditions.

Figure 14. Electromagnetic torque of the induction motor under healthy, faulty and reconfiguration conditions.

Under prefault conditions, the induction motor rotor speed and torque are maintained at constant values to meet the load requirement, as shown in Figures 13a and 14a. When the GOC and GSC faults are introduced, the values fluctuate, as can be seen in Figures $13 \mathrm{~b}, \mathrm{~d}$ and $14 \mathrm{~b}, \mathrm{~d}$, respectively. After the reconfiguration method is implemented, they regain their healthy-condition values, as shown in Figures $13 \mathrm{c}, \mathrm{e}$ and $14 \mathrm{c}, \mathrm{e}$, respectively.

\section{Conclusions}

The main aim of this paper was to introduce a novel fault reconfiguration technique by utilizing auxiliary switching cells to mitigate open and short circuit faults in a proposed 5-level RSMLI topology which is used in a MIMD system. The DWT-MRA methodology leads to accurate results for the analysis of faults in MIMD systems. It provides a simple but reliable fault analysis based on several signatures by using a FEXM, which identifies and classifies the fault types using prior information. Based on these signatures, a fault reconfiguration technique is initiated by switching the auxiliary switch cells with a reconfiguration switching state. The measured values of the decomposition feature rate $D_{f r}$ and averaged mean absolute deviation $\mathrm{M}_{\mathrm{ad}}$ are 0.9250 and 27.76 during the fault reconfiguration, which are approximately equal to the healthy condition values of 1 and 30.27, respectively, which underlines the effectiveness of the proposed system. The technique is applicable to any MIMD system with a high number of voltage levels and can mitigate both open and short circuit faults. In our experiments we validated the effectiveness of the approach.

Author Contributions: Conceptualization, A.S.V., M.R.M., A.A.S.; methodology, A.S.V., A.A.S., M.R.M.; software, A.S.V.; validation, A.S.V.; writing-original draft preparation, A.S.V., A.A.S., M.R.M.; writing-review and editing, A.S.V., A.A.S., M.R.M., P.L., C.P.S.; supervision, M.R.M.; project administration, M.R.M.; funding acquisition, A.A.S., M.R.M. All authors have read and agreed to the published version of the manuscript.

Funding: This work was partially supported by the National Key Research development Program of China (Grant No. 2017YFB0701700). This project was supported by University Malaysia Pahang (UMP) and A.S. Veerendra is working under UMP's Doctoral Research Scheme (DRS).

Conflicts of Interest: The authors declare no conflict of interest. 


\section{References}

1. Ojha, A.; Chaturvedi, P.; Mittal, A.; Jain, S. Carrier Based Common Mode Voltage Reduction Techniques in Neutral Point Clamped Inverter Based AC-DC-AC Drive System. J. Power Electron. 2016, 16, 142-152. [CrossRef]

2. Mahato, B.; Raushan, R.; Jana, K.C. Modulation and control of multilevel inverter for an open-end winding induction motor with constant voltage levels and harmonics. IET Power Electron. 2017, 10, 71-79. [CrossRef]

3. Sankala, A.; Korhonen, J.; Ström, J.; Luukko, J.; Silventoinen, P.; Komulainen, R.; Sarén, H.; Södö, N.; Isaksson, D. Modular double-cascade converter for high-power medium-voltage drives. IET Power Electron. 2015, 8, 1661-1669. [CrossRef]

4. Chandran, B.P.; Selvakumar, A.I.; Mathew, F.M. Integrating multilevel converters application on renewable energy sources-A survey. J. Renew. Sustain. Energy 2018, 10, 065502. [CrossRef]

5. Porru, M.; Serpi, A.; Marongiu, I.; Damiano, A. Suppression of DC-link voltage unbalance in three-level neutral-point clamped converters. J. Frankl. Inst. 2018, 355, 728-752. [CrossRef]

6. Abdullah, R.; Rahim, N.A.; Raihan, S.R.S.; Ahmad, A.Z. Five-Level Diode-Clamped Inverter with Three-Level Boost Converter. IEEE Trans. Ind. Electron. 2014, 61, 5155-5163. [CrossRef]

7. Raj, M.M.P.; Sundaram, S.S.M. Cascaded H-Bridge Five-Level Inverter for Grid-Connected Photovoltaic System Using Proportional-Integral Controller. Meas. Control. 2016, 49, 33-41. [CrossRef]

8. Matos, D.M.B.; Estima, J.O.; Cardoso, A.J.M. Fault Analysis of Three-Level NPC Inverters in Synchronous Reluctance Motor Drives. In Privacy and Identity Management. Facing up to Next Steps; Springer: Berlin, Germany, 2016; Volume 470, pp. $206-216$.

9. Veerendra, A.S.; Mohamed, M.R.; Sulaiman, M.H.; Sudhakar, K.; Peddakapu, K. Modelling and simulation of dual sourced front-end converter for hybrid electric vehicles. Int. J. Ambient. Energy 2020, 1-8. [CrossRef]

10. D'Aversa, A.; Hughes, B.; Patel, S. Challenges and Solutions of Protecting Variable Speed Drive Motors. In Proceedings of the 66th Annual Conference on Protective Relay Engineers, College Station, TX, USA, 8-11 April 2013; pp. $250-256$.

11. Lezana, P.; Pou, J.; Meynard, T.A.; Rodriguez, J.; Ceballos, S.; Richardeau, F. Survey on Fault Operation on Multilevel Inverters. IEEE Trans. Ind. Electron. 2010, 57, 2207-2218. [CrossRef]

12. Priya, Y.K.; Kumar, M.V. Analysis of various switch faults of the Three level Neutral point clamped inverter feeding induction motor drive. In Proceedings of the 2016 2nd International Conference on Advances in Electrical, Electronics, Information, Communication and Bio-Informatics (AEEICB), Chennai, India, 27-28 February 2016; pp. 580-586.

13. Trabelsi, M.; Boussak, M.; Gossa, M. Multiple IGBTs open circuit faults diagnosis in voltage source inverter fed induction motor using modified slope method. In Proceedings of the The XIX International Conference on Electrical Machines-ICEM 2010, Rome, Italy, 6-8 September 2010; pp. 1-6.

14. Estima, J.O.; Cardoso, A.J.M. A New Algorithm for Real-Time Multiple Open-Circuit Fault Diagnosis in Voltage-Fed PWM Motor Drives by the Reference Current Errors. IEEE Trans. Ind. Electron. 2013, 60, 3496-3505. [CrossRef]

15. Romero-Troncoso, R.D.J. Multirate Signal Processing to Improve FFT-Based Analysis for Detecting Faults in Induction Motors. IEEE Trans. Ind. Inf. 2016, 13, 1291-1300. [CrossRef]

16. Moussa, M.A.; Boucherma, M.; Khezzar, A. A Detection Method for Induction Motor Bar Fault Using Sidelobes Leakage Phenomenon of the Sliding Discrete Fourier Transform. IEEE Trans. Power Electron. 2016, 32, 5560-5572. [CrossRef]

17. Corral-Hernández, J.A.; Antonino-Daviu, J.A. Influence of the Start-up System in the Diagnosis of Faults in the Rotor of Induction Motors using the Discrete Wavelet Transform. Procedia Comput. Sci. 2016, 83, 807-815. [CrossRef]

18. Moosavi, S.; Kazemi, A.; Akbari, H. A comparison of various open-circuit fault detection methods in the IGBT-based DC/AC inverter used in electric vehicle. Eng. Fail. Anal. 2019, 96, 223-235. [CrossRef]

19. Wu, F.; Hao, Y.; Zhao, J.; Liu, Y. Current similarity based open-circuit fault diagnosis for induction motor drives with discrete wavelet transform. Microelectron. Reliab. 2017, 75, 309-316. [CrossRef]

20. Cheon, J.-M.; Kim, C.-K.; Lee, J.-M.; Kim, S.-J.; Kwon, S. A New Fault Detectior for Three-Phase Half-Wave Converter Using Wavelet Transform. IFAC Proc. Vol. 2003, 36, 945-950. [CrossRef]

21. Balamurugan, C.R.; Natarajan, S.; Bensraj, R.; Shanthi, B. A Review on Modulation Strategies of Multi Level Inverter. Indones. J. Electr. Eng. Comput. Sci. 2016, 3, 681. [CrossRef]

22. Xiao, M.; Xu, Q.; Ouyang, H. An Improved Modulation Strategy Combining Phase Shifted PWM and Phase Disposition PWM for Cascaded H-Bridge Inverters. Energies 2017, 10, 1327. [CrossRef]

23. Chavali, P.S.; Rao, P.V.R.; Vani, M.U. A Novel Multilevel Inverter with Reduced Number of Switches Using Simplified PWM Technique. J. Inst. Eng. Ser. B 2020, 101, 203-216. [CrossRef]

24. Ahmed, I.; Borghate, V.B. Simplified space vector modulation technique for seven-level cascaded H-bridge inverter. IET Power Electron. 2014, 7, 604-613. [CrossRef]

25. Gaeid, K.S.; Maher, R.A.; Lazim, A.J. Multilevel Inverter Fault-Tolerant Control with Wavelet Index in Induction Motor. J. Electr. Eng. Technol. 2019, 14, 1179-1191. [CrossRef]

26. Bialasiewicz, J.T.; Gonzalez, D.; Balcells, J.; Gago, J. Wavelet-Based Approach to Evaluation of Signal Integrity. IEEE Trans. Ind. Electron. 2012, 60, 4590-4598. [CrossRef]

27. Keswani, R.A.; Suryawanshi, H.M.; Ballal, M.S. Multi-resolution analysis for converter switch faults identification. IET Power Electron. 2015, 8, 783-792. [CrossRef] 
28. Ananthan, S.N.; Padmanabhan, R.; Meyur, R.; Mallikarjuna, B.; Reddy, M.J.B.; Mohanta, D.K. Real-time fault analysis of transmission lines using wavelet multi-resolution analysis based frequency-domain approach. IET Sci. Meas. Technol. 2016, 10, 693-703. [CrossRef]

29. Jung, S.-M.; Park, J.-S.; Kim, H.-W.; Cho, K.-Y.; Youn, M.-J. An MRAS-Based Diagnosis of Open-Circuit Fault in PWM VoltageSource Inverters for PM Synchronous Motor Drive Systems. IEEE Trans. Power Electron. 2012, 28, 2514-2526. [CrossRef]

30. Kompella, K.D.; Mannam, V.G.R.; Rayapudi, S.R. DWT based bearing fault detection in induction motor using noise cancellation. J. Electr. Syst. Inf. Technol. 2016, 3, 411-427. [CrossRef]

31. Kim, I.-S. On-line fault detection algorithm of a photovoltaic system using wavelet transform. Sol. Energy 2016, 126, 137-145. [CrossRef]

32. Lopez-Hernandez, M.; Rangel-Magdaleno, J.; Peregrina-Barreto, H.; Ramirez-Cortes, J. Detection of broken bars on induction motors using MODWT. In Proceedings of the 2018 IEEE International Instrumentation and Measurement Technology Conference (I2MTC), Houston, TX, USA, 14-17 May 2018; pp. 1-5.

33. Chen, W.; Bazzi, A.M. Logic-Based Methods for Intelligent Fault Diagnosis and Recovery in Power Electronics. IEEE Trans. Power Electron. 2017, 32, 5573-5589. [CrossRef]

34. AbdelGhani, A.B.-B.; Ben-Abdelghani, H.; Richardeau, F.; Blaquiere, J.-M.; Mosser, F.; Slama-Belkhodja, I. Versatile Three-Level FC-NPC Converter with High Fault-Tolerance Capabilities: Switch Fault Detection and Isolation and Safe Postfault Operation. IEEE Trans. Ind. Electron. 2017, 64, 6453-6464. [CrossRef]

35. Chen, W.; Hotchkiss, E.; Mademlis, C.; Bazzi, A.M. Integrated fault diagnosis and recovery in NPC multi-level inverters. In Proceedings of the 2017 IEEE 11th International Symposium on Diagnostics for Electrical Machines, Power Electronics and Drives (SDEMPED), Tinos, Greece, 29 August-1 September 2017; pp. 415-421. [CrossRef]

36. Chen, W.; Hotchkiss, E.; Bazzi, A. Reconfiguration of NPC multi-level inverters to mitigate short circuit faults using back-to-back switches. CPSS Trans. Power Electron. Appl. 2018, 3, 46-55. [CrossRef]

37. Shen, Y.; Miao, B.; Wu, D.; Ibrahim, K.A. Fault-Tolerant Control Strategy for Neutral-Point-Clamped Three-Level Inverter. J. Control. Sci. Eng. 2018, 2018, 1-9. [CrossRef] 